\title{
Changes of physiochemical properties and biological activity during the fermentation of Doenjnag with bitter melon (Momordica charantia L.)
}

\author{
Chung Eun Hwang ${ }^{1}$, Ok Soo Joo ${ }^{1}$, Jin Hwan Lee ${ }^{2}$, Yeong Hun Song ${ }^{3}$, \\ In Guk Hwang ${ }^{4}$, Kye Man Cho ${ }^{1 *}$ \\ ${ }^{1}$ Department of Food Science, Gyeongnam National University of Science and Technology, Jinju 52725, Korea \\ ${ }^{2}$ National Institute of Chemical Safety, Ministry of Environment, Daejeon 34111, Korea \\ ${ }^{3}$ Division of Applied Life Science (BK21 plus), IALS, Gyeongsang National University, Jinju, 52828, Korea \\ ${ }^{4}$ Department of Agrofood Resources, National Academy of Agricultural Science, Rural Development Administration (RDA), \\ Wanju 55365, Korea
}

\section{여주 함유 된장의 발효 중 이화학적 특성 및 생리활성의 변화}

\author{
황정 은 ${ }^{1} \cdot$ 주옥수 ${ }^{1} \cdot$ 이진환 ${ }^{2} \cdot$ 송영 훈 ${ }^{3} \cdot$ 황인국 $^{4} \cdot$ 조계만 ${ }^{*}$ \\ ${ }^{1}$ 경남과학기술대학교 식품과학부, ${ }^{2}$ 환경부 화학물질안전원, \\ ${ }^{3}$ 경상대학교 응용생명과학부(BK21 Plus), 농업생명과학연구원, ${ }^{4}$ 농촌진흥청 국립농업과학원 농식품자원부
}

\begin{abstract}
This study evaluated the changes of physiochemical properties, phytochemical compounds (isoflavones and phenolic acids), and biological activity during the fermentation of Doenjang without and with bitter melon powder (BMP). The $\mathbf{p H}$ decreased from 6.41-5.83 to 5.81-5.24, during the fermentation of Doenjang, while the acidity increased from $0.42-0.65 \%$ to $1.28-1.48 \%$. The viable cell numbers of Bacillus and Yeast, salinity, and total amino acid contents increased at the end fermentation (60 day). Also, the fermented Doenjang (FD) with 10\% BMP showed the highest $\mathrm{y}$-aminobutyric acid (GABA, $129.87 \mathrm{mg} / 100 \mathrm{~g}$ ) contents, among all the Doenjang samples. The FD exhibited significantly higher inhibitory activities than unfermented Doenjang (UFD) on radicals and a-glucosidase. The phytochemical compounds including isoflavone-aglycones and phenolic acids increased, whereas isoflavoneglycosides decreased in the BM following fermentative processing. Moreover, the total phenolic, isoflavone-aglycone, and phenolic acid contents were markedly increased, leading to a general increase in antioxidant and a-glucosidase inhibition activities after fermentation. These results suggest that BMP may be used to prepare a new type of fermented Doenjang with improved antioxidant and antidiabetic activities.
\end{abstract}

Key words : bitter melon, Doenjang, phytochemicals, antioxidant, a-glucosidase inhibition

\section{서 론}

전통된장은 메주로 장을 담근 후 장물을 떠내고 남은 건더기로 만든 장으로 정의되고 이미 오래전부터 한국인의

*Corresponding author. E-mail : kmcho@gntech.ac.kr Phone : 82-55-751-3272, Fax : 82-55-751-3279

Received 4 January 2017; Revised 2 February 2017; Accepted 17 February 2017.

Copyright (c) The Korean Society of Food Preservation. All rights reserved.
애용 식품으로 이용되어 왔으며 단백질과 지방 함량이 높아 영양적으로도 아주 우수한 발효식품이다(1). 된장은 제조 방식에 따라 Aspergillus oryzae 등의 국균을 이용한 개량식 과 전통식으로 구별되며 현재에는 생활환경의 변화로 인해 산업화에 따른 개량식 된장의 소비가 급증한 상태이다(2). 된장의 주성분인 대두는 본래 항산화 물질을 함유하고 있지 만 발효와 숙성 과정 중에 새로이 생성되는 이소플라본 비배당체, 유리아미노산, 갈변물질 등을 함유하게 된다. 이 러한 기능성 물질들에 의해 된장은 항암효과(3), 혈전용해 능(4), 면역증가(5) 등의 수많은 이점을 지니고 있어 이제는 
조미료 역할보다는 항암식품으로 더욱 주목을 받고 있다. 따라서 이러한 전통식품을 현대인의 기호에 맞게 변형시킨 결과 다시마, 미역, 멸치 분말 첨가 된장(2), 버섯된장(6), 버섯 균사체 된장(7) 등 기능성 소재를 첨가하여 강화시키 는 연구가 활발히 진행되고 있다.

여주(Momordica charantia L.)는 쓴맛과 향을 지닌 한해 살이 박과식물로 서양에서는 bitter melon, 아프리카에서는 wild cucumber, 일본은 고야, 한국에서는 여주라는 다양한 이름을 가지고 있다(8). 일본에서는 이미 오래전부터 여주 산업이 발달한 상태이며 동남아시아에서는 기능성 채소로 많이 사용한다고 알려져 있다(9). 한국에서는 주로 관상용 으로만 사용하였으며 식욕 저하 시 여주의 쓴맛 성분이 위를 자극하여 소화액 분비를 촉진시키므로 강장작용에 이용하였고 한방에서는 해열 및 거담 등의 약용작물로 쓰이 고 있다(10). 하지만 여주의 강한 쓴맛 때문에 여전히 이용 하는데 어려움을 겪고 있어 볶음 처리를 하여 쓴맛을 저감 시키는 연구 결과도 있다(8). 한편 여주는 비타민 $\mathrm{C}$ 와 $\mathrm{A}$, $\mathrm{Fe}$ 등을 다량 함유하고 있으며 항암, 항괴사, 항고혈당, 항당 뇨의 효능이 있다 $(11,12)$. 특히 여주의 열매와 종자에 함유 되어있는 charantin이라는 성분은 항당뇨에 큰 효과가 있다 고 알려져 있다(8). 당뇨는 완치가 어렵지만 식이요법으로 조절이 필요한 질환으로 남미나 인도 등에서는 당뇨 환자의 $30 \%$ 에 대해서 여주를 대체식품으로 사용하지만 한국의 경우에는 아직까지 대중적인 소비가 이루어지지 않고 있다 (13).

따라서 본 연구에서는 여주의 이용성 증대를 위해 여주 분말을 첨가하여 된장을 제조하고 발효 중 품질 특성, phytochemicals, 항산화 활성과 a-glucosidase 저해활성을 분석하였다.

\section{재료 및 방법}

\section{실험재료 및 시약}

된장 제조에 사용된 콩은 경상남도 함양군 농협 가공사 업소에서 제공받아 사용하였다. 여주는 함양군 수동면 일 대에서 생산된 것을 함양영농조합법인으로부터 제공받아 사용하였다. Phenolic acid 표준품(gallic acid, chlorogenic acid, para-hydroxylbenzoic acid, protocatechuic acid, vanillic acid, para-coumraic acid, ferulic acid, veratric acid 및 transcinnamic $\operatorname{acid}(t-\mathrm{Cn} A))$ 은 Sigma Chemical Co.(St. Louis, MO, USA)에서 구입하였다. 이소플라본 비배당체(daidzein, glycitein 및 genistein)는 Sigma-Aldrich사(St. Louis, MO, USA)에서 구입하였고 배당체(daidzin, glycitin 및 genistin) 는 Indofine사(Hillsborough, NJ, USA)에서 구입하였다. Folin - Cicalteu phenol, 2,2-diphenyl-1-picrylhydrazyl(DPPH), potassium ferricyanide, trichloroacetic acid(TCA), 2,2'-
Azino-bis(3-ethylbenzothiazoline-6-sulfonic acid) diammonium salt(ABTs), 2,4,6-tri(2-pyridyl)-1,3,5-triazine(TPTZ), 2thiobarbituric acid, trichloroacetic acid, 2- deoxyribose, $\rho$ -nitrophenyl-a-D-glucopyranoside(NPG), a-glucosidase(Type I : from Bakers Yeast) 또한 Sigma-Aldrich사에서 구입하여 사용하였다.

\section{발효 균주 배양 및 여주 첨가 된장 제조}

발효 균주는 이전 연구에서 청국장 제조 시 이취가 없는 Bacillus subtilis CSY191 균주를 사용하였으며(14), 밀 곡자 제조에 사용된 곰팡이는 Rhizopus oryzae CCS01를 사용하 였다(15). 된장 제조에 앞서 밀 곡자는 밀가루 $2 \mathrm{~kg}$ 에 $R$ oryzae CCS01현탁액 $90 \mathrm{~mL}$ 를 첨가하여 $20^{\circ} \mathrm{C}$ 에서 48 시간 배양한 후 $55^{\circ} \mathrm{C}$ 에서 2 일간 건조시켜 분말 형태로 제조하였 다. 청국장 제조는 콩을 12 시간 수침한 후 물기를 제거하고 $121^{\circ} \mathrm{C}$ 에서 1 시간 증자 처리를 하였다. 이후 적당히 시키고 미리 배양한 B. subtilis CSY191 균주 배양액을 $2.5 \%$ 접종하 여 $37^{\circ} \mathrm{C}$ 에서 3 일 발효 시킨 후 $55^{\circ} \mathrm{C}$ 에서 2 일간 건조하여 분말 형태로 제조하였다. 한편 여주 첨가량은 된장 총 부피 의 무첨가(대조군)와 5 및 $10 \%$ 에 해당하는 양을 분말 형태 로 첨가하여 여주 된장을 제조하였으며 멸균된 유리병에 담아 상온에서 6 주간 숙성시키면서 실험을 진행하였다.

\section{$\mathrm{pH}$, 총산도 및 염도}

$\mathrm{pH}$ 는 시료 $5 \mathrm{~g}$ 을 증류수 $50 \mathrm{~mL}$ 에 용해하여 여과한 여액 을 일정량 취하여 $\mathrm{pH}$ meter(MP $220 \mathrm{pH}$ meter, Jenway, England)를 사용하여 측정하였다. 총산은 여액에 대해서 $0.1 \mathrm{~N} \mathrm{NaOH}$ 용액으로 $\mathrm{pH}$ 8.4까지 중화시킨 후 초산 양으로 환산하였다. 염도는 된장 시료 $5 \mathrm{~g}$ 에 증류수 $50 \mathrm{~mL}$ 를 첨가 하여 혼합한 후 원심분리 하여 얻은 상등액을 염도계(Atago ES-421, Atago Co., Tokyo, Japan)로 측정하였다.

\section{생균수}

여주 첨가 된장 발효 과정 중 B. subtilis CSY191 균주와 효모의 생균수를 측정하였다. 여주 된장 $10 \mathrm{~g}$ 에 멸균 증류수 $90 \mathrm{~mL}$ 를 가하고 혼탁 시킨 후 이를 적절히 희석하여 사용하 였으며 고초균의 경우에는 tryptic soy agar(TSA) 배지를 사용하였고 효모는 chloramphenicol $100 \mu \mathrm{g} / \mathrm{mL}$ 가 함유된 potato dextrose agar(PDA) 배지에 도말한 후 $30^{\circ} \mathrm{C}$ 에서 48 시 간 동안 배양하여 형성된 집락을 계수하여 생균수를 $\mathrm{CFU} / \mathrm{g}$ 으로 나타내었다.

\section{유리아미노산 함량}

여주 첨가 된장 $1 \mathrm{~g}$ 에 증류수 $5 \mathrm{~mL}$ 를 가해 $60^{\circ} \mathrm{C}$ 에서 1 시간 가수분해 시킨 후 $10 \% 5$-sulfosalicylic acid $1 \mathrm{~mL}$ 를 첨가하여 $4{ }^{\circ} \mathrm{C}$ 에서 2 시간 방치시켜 단백질을 침전시켰다. 3 분간 원심분리 후 syringe 필터로 여과 하여. $60^{\circ} \mathrm{C}$ 에서 감압 
농축하였다. 농축 후에는 $\mathrm{pH} 2.2$ lithium buffer $2 \mathrm{~mL}$ 에 용해 하고 $0.45 \mu \mathrm{m}$ membrane filter로 여과시켜 아미노산 자동분 석기로 분석하였다.

\section{추출물 제조}

발효 기간별 여주 첨가 된장은 동결 건조하여 얻은 분말 을 $50 \%$ 메탄올에 12 시간 추출하고 $0.45 \mu \mathrm{m}$ membrane filter(Dismic-25CS, Toyoroshikaisha, Ltd., Tokyo, Japan)로 여과하여 제조하였다. 이 추출물은 총 phenolics, isoflavone 함량 및 항산화 활성 등을 측정하는데 사용하였다.

\section{총 phenolics 분석}

추출물 $0.5 \mathrm{~mL}$ 를 시험관에 분주하고 $25 \% \mathrm{Na}_{2} \mathrm{CO}_{3}$ 용액 $0.5 \mathrm{~mL}$ 를 첨가하여 3 분간 정치시키고 다시 $2 \mathrm{~N}$ FolinCiocalteu phenol 시약 $0.25 \mathrm{~mL}$ 를 첨가하여 혼합한 다음 상온에서 1시간 동안 발색시켰다. 이후 분광광도계(Spectronic $2 \mathrm{D})$ 를 이용하여 $750 \mathrm{~nm}$ 에서 흡광도를 측정하였고 gallic acid를 이용하여 작성한 표준곡선으로부터 함량을 구하였 다(14).

\section{Isoflavones 유도체 분석}

Isoflavone 함량 분석은 Cho와 Joo 등(14)의 방법에 준하 여 High performance liquid chromatography(HPLC, Agilent 1200 series, Agilent Co., Forest Hill, Australia)로 분석하였 다. 분석 column은 Lichrophore $100 \mathrm{RP}$ C18 column(4.6×250 $\mathrm{mm}, 5 \mu \mathrm{m}$, Merck, Darmstadt, Germany)을 사용하였고 이동 상 용매는 $0.2 \%$ glacial acetic acid in water(solution A)와 $0.2 \%$ acetonitrile in glacial acetic acid(solution B)로 분석하 였다. 이동상 조건은 A 용매 기준으로 0분-100\%, 15 분-90\%, 25 분-80\%, 35분-75\%, 45 분-65\% 및 50분-65\%로 유지하였 다. 시료는 $20 \mu \mathrm{L}$ 를 주입하였으며, 이동상 속도는 $30^{\circ} \mathrm{C}$ 에서 $1 \mathrm{~mL} /$ 분으로 유지하였다. 검출기는 diode array detector $(\mathrm{DAD})$ 를 사용하여 $\mathrm{UV} 254 \mathrm{~nm}$ 에서 검출하였다.

\section{Phenolic acids 유도체 분석}

Phenolic acid 분석은 Lee 등(16)의 분석법을 변형하여 HPLC(Agilent 1200 series, Agilent Co.)로 분석하였다. 분석 column은 XTerra ${ }^{\mathrm{TM}} \mathrm{RP}$ C8 column $(4.6 \times 250 \mathrm{~mm}, 5 \mu \mathrm{m}$, Waters Corp., Milford, MA, USA)과 HPLC(Agilent 1200 series, Agilent Co.)을 이용하여 분석하였다. 이동상 용매는 $2 \%$ glacial acetic acid in water(solution $\mathrm{A}$ )와 $2 \%$ glacial acetic acid in acetonitrile(solution B)로 분석하였고, 이동상 조건은 solvent B 기준으로 각각 $10,15,20,25,30,35,40,45$, 55 및 $60 \mathrm{~min}$ 동안 $15 \%, 5 \%, 15 \%, 5 \%, 10 \%, 50 \%, 50 \%$, $60 \%, 80 \%$ 및 90\%로 유지시켰다. 시료는 $20 \mu \mathrm{L}$ 를 주입하였 고 이동상의 속도는 $30^{\circ} \mathrm{C}$ 에서 $1 \mathrm{~mL} / \mathrm{min}$ 로 유지하였고 phenolic acids 물질은 diode array UV detector(Agilent 1200 series, Agilent Co.)의 흡광도 $280 \mathrm{~nm}$ 에서 정량하였다.

\section{$\mathrm{DPPH}$ 라디칼 소거 활성}

Hwang 등(17)의 방법을 따라 라디칼 소거활성을 측정하 였다. $1.5 \times 10^{-4} \mathrm{M} \mathrm{DPPH}(1,1$-diphenyl-2-picryhdrazyl) 용액 $0.8 \mathrm{~mL}$ 와 여과액 및 발효 원심분리 상등액 $0.2 \mathrm{~mL}$ 를 가한 후 10 초간 votex하고 실온에서 30 분 방치한 후 분광광도계 (Spectronic 2D)를 이용하여 $525 \mathrm{~nm}$ 에서 흡광도를 측정하 였다. 각 실험은 3회 반복하여 수행하였다. 음성 대조구 실험은 시료 대신에 증류수를 $0.2 \mathrm{~mL}$ 를 취하여 실험하였다. $\mathrm{DPPH}$ 라디칼 소거활성은 실험구와 음성 대조구의 흡광도 를 구하여 백분율(\%)로 표시하였다.

\section{ABTS 라디칼 소거 활성}

$7 \mathrm{mM} \mathrm{ABTs}$ 용액과 $2.45 \mathrm{mM}$ Potassium persulfate $\left(\mathrm{K}_{2} \mathrm{~S}_{2} \mathrm{O}_{8}, \mathrm{FW} 270.3\right.$, Sigma 9392)을 1:1로 섞고, 실온의 어두 운 곳에서 12-16시간 보관하여 $\mathrm{ABTS} \operatorname{radical}\left(\mathrm{ABTS}^{+}\right)$을 만 들었다. $\mathrm{ABTS}$ radical $\left(\mathrm{ABTS}^{+}\right)$은 $732 \mathrm{~nm}$ 에서 absorbance가 $0.7 \pm 0.02$ 가 되도록 메탄올로 희석하여 사용하였다. 메탄올 로 희석된 $\mathrm{ABTS}$ 용액(Abs $0.7 \pm 0.02) 0.9 \mathrm{~mL}$ 와 여과액 및 발효 원심분리 상등액 $0.1 \mathrm{~mL}$ 를 섞고, 정확히 3 분 후 분광광 도계(Spectronic 2D)를 이용하여 $732 \mathrm{~nm}$ 에서 흡광도를 측 정하였다(16).

\section{Hydroxyl $(\cdot \mathrm{OH})$ 라디칼 소거활성}

$\operatorname{Hydroxyl}(\cdot \mathrm{OH})$ 라디칼 소거능은 $10 \mathrm{mM} \mathrm{FeSO} 4.7 \mathrm{H}_{2} 0$ EDTA $0.2 \mathrm{~mL}, 10 \mathrm{mM}$ 2-deoxyribose $0.2 \mathrm{~mL}, 10 \mathrm{mM} \mathrm{H}_{2} \mathrm{O}_{2}$ $0.2 \mathrm{~mL}$, 추출물 $1.4 \mathrm{~mL}$ 를 혼합하고 $37^{\circ} \mathrm{C}$ 에서 4 시간 동안 반응시켰다. 이 혼합액에 $1 \%$ thiobarbituric acid와 $2.8 \%$ trichloroaceric acid를 각각 $1 \mathrm{~mL}$ 를 가하여 $100^{\circ} \mathrm{C}$ 에서 20 분 간 가열하여 발색 및 냉각시킨 후 $520 \mathrm{~nm}$ 에서 흡광도를 측정하였다. 음성대조구 실험은 시료 대신에 PBS 완충액 $\left(\mathrm{NaCl} 8.76 \mathrm{~g}, \mathrm{NaH}_{2} \mathrm{PO}_{4} 0.11 \mathrm{~g}, \mathrm{Na}_{2} \mathrm{HPO}_{4} 0.596 \mathrm{~g}\right)$ 을 사용하 였고 라디칼 소거능은 시료용액의 첨가구와 무첨가구 사이 의 흡광도의 차이를 백분율(\%)로 나타내었다(8).

\section{$\mathrm{a}-$ Glucosidase 저해 활성}

여과액 혹은 발효 원심분리 상등액 $50 \mu \mathrm{L}, 0.5 \mathrm{U} / \mathrm{mL}$ a -glucosidase 효소액 $50 \mu \mathrm{L}, 200 \mathrm{mM}$ sodium phosphate buffer(pH 6.8) $50 \mu \mathrm{L}$ 와 혼합하여 $37^{\circ} \mathrm{C}$ 에서 10 분간 예비 배양한 후 sodium phosphate buffer(pH 6.8)에 $5 \mathrm{mM}$ p-nitrophenol-a-D-glucopyranoside(NPG)을 $100 \mu \mathrm{L}$ 가하여 $37^{\circ} \mathrm{C}$ 에서 10 분간 반응시켰다. 반응액에 $100 \mathrm{mM} \mathrm{Na}_{2} \mathrm{CO}_{3}$ $750 \mu \mathrm{L}$ 로 반응을 정지시키고 $420 \mathrm{~nm}$ 에서 흡광도를 측정하 고 저해율을 계산하였다. 음성 대조구로 $100 \%$ 증류수를 사용하였다(8). 


\section{통계처리}

실험 결과는 SPSS 12.0 package를 사용하여 분산 분석을 수행하였고 평균표준편차로 나타내었다. 각 시료 분석 결과에 대한 유의성 검정은 분산 분석 후 $\mathrm{p}<0.05$ 수준에서 Duncan's multiple range test를 실시하였다.

\section{결과 및 고찰}

\section{여주 첨가 된장 발효 중 이화학적 특성 변화}

여주 첨가 된장의 이화학적 특성 변화는 Table 1 과 같았다. $\mathrm{pH}$ 는 발효 후 증가하였고, 이에 반대로 산도는 증가하였 다. 발효 초기 된장의 $\mathrm{pH}$ 는 여주 첨가량이 증가할수록 점차 낮아지는 경향을 나타내었다. 여주를 첨가하지 않은 된장 의 초기 $\mathrm{pH}$ 는 6.41 이었고 $5 \%$ 는 6.05로 이보다 좀 더 낮게 측정되었고 $10 \%(5.83)$ 역시 첨가량에 비례하여 $\mathrm{pH}$ 가 낮아 졌다. 또한 발효 60 일째 $\mathrm{pH}$ 는 감소하는 경향을 나타내었고 $10 \%$ 여주를 첨가한 된장의 $\mathrm{pH}$ 는 5.24 로 이들 중 가장 낮은 것으로 나타났다. 산도는 $\mathrm{pH}$ 감소에 따라 조금씩 증가하였 고 이 역시 $10 \%$ 여주 첨가 된장이 발효 60 일째 $1.48 \%$ 로 가장 높은 산미를 형성하였다(Table 1).

염도는 발효 후 약간 증가하는 경향을 보여 여주를 첨가 하지 않은 된장은 $11.8 \%$ 에서 $12.6 \%$ 로, $5 \%$ 첨가 된장은 $11.4 \%$ 에서 $13.8 \%$ 로, $10 \%$ 첨가 된장은 $11.8 \%$ 에서 $13.2 \%$ 로 증가하였다. 한편 Bacillus와 효모의 생균수 측정 결과 균수 는 발효 후 약간 증가하였으며, Bacillus 균주는 발효 후 각각 $10.7 \log \mathrm{CFU} / \mathrm{g}, 11.46 \log \mathrm{CFU} / \mathrm{g}$ 및 $9.72 \log \mathrm{CFU} / \mathrm{g}$ 있었고, 효모 균수는 각각 $7.02 \log \mathrm{CFU} / \mathrm{g}, 6.86 \log \mathrm{CFU} / \mathrm{g}$ 및 $6.84 \log \mathrm{CFU} / \mathrm{g}$ 있었다(Table 1).

일반적으로 된장은 발효 과정 중에 발효 미생물에 의해 당과 단백질이 분해되어 각종 유기산과 유리아미노산이 생성되므로 결과적으로 $\mathrm{pH}$ 는 감소하고 총산은 증가한다고 알려져 있다(18). Hong 및 Rhee (19)도 된장 숙성 중 유기산
이 생성되어 $\mathrm{pH}$ 가 감소한다고 보고하였고 Yang 등(20)도 acetic acid, lactic acid와 같은 유기산이 검출된다고 하였으 므로 본 연구에서도 여러 종류의 유기산이 생성된 것으로 추측된다. Cho 등(18)은 마늘 된장 숙성 중에 소금 농도가 증가할수록 Bacillus 및 효모의 수가 모두 완만히 감소하였 고 이는 삼투압 영향을 받은 것으로 판단된다. Jun 및 $\operatorname{Song}(21)$ 은 마 첨가 된장 숙성 중에 Bacillus보다 효모의 수가 더 많다는 연구 결과를 볼 때 이는 된장 제조 시 첨가되 는 부재료 종류에 따라 미생물의 생육 양상이 달라지는 것으로 판단된다. 따라서 본 연구에서는 효모 균수는 조금 씩 감소하였으나 Bacillus 균주들은 오히려 증가했으므로 여주 첨가량에 따른 미생물 생육에는 큰 영향을 받지 않는 것으로 추측 된다. 한편 Cho 등(14)의 연구에 따르면 여주를 첨가하여 제조한 청국장의 관능평가를 실시한 결과 외관은 일반 청국장보다 낮은 점수를 획득하였으나 맛과 향 그리고 전체적인 기호도 측면에서는 여주 청국장이 높은 점수를 획득하였고 특히 여주 첨가량이 증가할수록 청국장 특유의 냄새는 감소하는 것으로 보고하였다. 본 연구 또한 여주 첨가량이 많을수록 이취도가 감소하였고 이는 Cho 등(14) 의 결과와 일치하였다. 따라서 부재료로 첨가된 여주는 콩 발효 과정 중 미생물 효소작용 등에 의해 특유의 쓴맛이 감소될 것으로 기대된다. 한편 $\mathrm{Ahn}$ 등(22)은 여주를 볶음처 리 함으로써 특유의 쓴맛 감소 효과를 보고하였으므로 볶음 처리 후 부재료로 첨가한다면 콩 발효식품의 맛과 향을 살리면서 여주 특유의 쓴맛 감소 효과를 볼 수 있을 것으로 사료된다.

\section{여주 첨가 된장 발효 중 유리아미노산 함량 변화}

여주 첨가 된장의 유리아미노산 함량을 분석한 결과는 Table 2에 나타내었다. 비필수 아미노산 중 phosphoserine은 발효 초기에는 검출되었지만 발효 후에는 검출되지 않았고 $10 \%$ 여주를 첨가한 된장에서만 발효 후에 $50.38 \mathrm{mg} / 100$ $\mathrm{g}$ 이 생성되었다. Taurine은 모두 발효 초기에는 검출되지

Table 1. Changes of $\mathrm{pH}$, acidity, salinity, and viable cell numbers during the fermentation of Doenjang without and with bitter melon

\begin{tabular}{|c|c|c|c|c|c|c|}
\hline \multirow{3}{*}{ Contents } & \multicolumn{6}{|c|}{ Added bitter melon powder concentration (\%) } \\
\hline & \multicolumn{2}{|c|}{0} & \multicolumn{2}{|c|}{5} & \multicolumn{2}{|c|}{10} \\
\hline & $\mathrm{UFD}^{1)}$ & $\mathrm{FD}^{2)}$ & UFD & FD & UFD & FD \\
\hline $\mathrm{pH}$ & $6.41 \pm 0.26^{33)}$ & $5.81 \pm 0.29^{\mathrm{a}}$ & $6.05 \pm 0.30^{\mathrm{a}}$ & $5.45 \pm 0.22^{\mathrm{a}}$ & $5.83 \pm 0.23^{\mathrm{a}}$ & $5.24 \pm 0.26^{\mathrm{a}}$ \\
\hline Acidity (\%, as acetic acid) & $0.42 \pm 0.02^{\mathrm{b}}$ & $1.28 \pm 0.03^{\mathrm{a}}$ & $0.62 \pm 0.07^{\mathrm{b}}$ & $1.4 \pm 0.03^{\mathrm{a}}$ & $0.65 \pm 0.05^{\mathrm{b}}$ & $1.48 \pm 0.06^{\mathrm{a}}$ \\
\hline Salinity (\%, as $\mathrm{NaCl})$ & $11.8 \pm 0.27^{\mathrm{a}}$ & $12.6 \pm 0.63^{\mathrm{a}}$ & $11.4 \pm 0.37^{\mathrm{a}}$ & $13.8 \pm 0.69^{\mathrm{a}}$ & $11.8 \pm 0.31^{\mathrm{a}}$ & $13.2 \pm 0.61^{\mathrm{a}}$ \\
\hline \multicolumn{7}{|c|}{ Viable cell numbers (log $\mathrm{CFU} / \mathrm{g}$ ) } \\
\hline Bacillus & $9.11 \pm 0.36^{\mathrm{a}}$ & $10.70 \pm 0.54^{\mathrm{a}}$ & $9.11 \pm 0.55^{\mathrm{a}}$ & $11.46 \pm 046^{\mathrm{a}}$ & $9.11 \pm 0.36^{\mathrm{a}}$ & $9.72 \pm 0.39^{\mathrm{a}}$ \\
\hline Yeast & $6.39 \pm 0.26^{\mathrm{a}}$ & $7.02 \pm 0.28^{\mathrm{a}}$ & $6.39 \pm 0.26^{\mathrm{a}}$ & $6.86 \pm 0.27^{\mathrm{a}}$ & $6.39 \pm 0.26^{\mathrm{a}}$ & $6.84 \pm 0.27^{\mathrm{a}}$ \\
\hline
\end{tabular}

\footnotetext{
${ }^{1)} \mathrm{UFD}$, Unfermented Doenjang (0 day).
}

${ }^{2)} \mathrm{FD}$, Fermented Doenjang (60 day).

${ }^{3)}$ All values are means of determination in three independent experiments. Means with different lowercase letters $(a-b)$ indicate significant $(p<0.05)$ differences of unfermented Doenjang and fermented Doenjang by Duncan's multiple range test. 
Table 2. Changes of free amino acid contents during the fermentation of Doenjang without and with bitter melon

\begin{tabular}{|c|c|c|c|c|c|c|}
\hline \multirow{3}{*}{ Contents $(\mathrm{mg} / 100 \mathrm{~g})$} & \multicolumn{6}{|c|}{ Added bitter melon powder concentration (\%) } \\
\hline & \multicolumn{2}{|c|}{0} & \multicolumn{2}{|c|}{5} & \multicolumn{2}{|c|}{10} \\
\hline & $\mathrm{UFD}^{1)}$ & $\mathrm{FD}^{2)}$ & UFD & FD & UFD & FD \\
\hline \multicolumn{7}{|l|}{ Non-essential amino acids } \\
\hline Phosphoserine & $67.25 \pm 2.69^{a 3)}$ & $\mathrm{ND}^{4)}$ & $\mathrm{ND}$ & $45.03 \pm 1.80^{\mathrm{b}}$ & $\mathrm{ND}$ & $50.38 \pm 2.02^{\mathrm{b}}$ \\
\hline Taurine & $\mathrm{ND}$ & $33.46 \pm 1.34^{\mathrm{a}}$ & $\mathrm{ND}$ & $10.60 \pm 0.42^{\mathrm{b}}$ & $\mathrm{ND}$ & $15.38 \pm 0.62^{\mathrm{b}}$ \\
\hline Phosphoetanolamine & $19.04 \pm 0.76^{d}$ & $130.46 \pm 5.22^{\mathrm{a}}$ & $43.65 \pm 1.75^{\mathrm{c}}$ & $38.95 \pm 1.56^{\mathrm{c}}$ & $22.67 \pm 0.91^{\mathrm{d}}$ & $72.10 \pm 2.88^{\mathrm{b}}$ \\
\hline Urea & $\mathrm{ND}$ & $\mathrm{ND}$ & $427.79 \pm 17.11^{\mathrm{a}}$ & $\mathrm{ND}$ & $105.20 \pm 4.21^{b}$ & $\mathrm{ND}$ \\
\hline Proline & $83.28 \pm 3.33^{\mathrm{e}}$ & $311.03 \pm 12.44^{\mathrm{c}}$ & $105.53 \pm 4.22^{\mathrm{d}}$ & $349.14 \pm 13.97^{b}$ & $110.86 \pm 4.43^{\mathrm{d}}$ & $482.05 \pm 19.28^{\mathrm{a}}$ \\
\hline Aspartic acid & $111.59 \pm 4.46^{\mathrm{f}}$ & $440.83 \pm 17.63^{b}$ & $166.65 \pm 6.67^{\mathrm{e}}$ & $332.89 \pm 13.32^{\mathrm{c}}$ & $182.03 \pm 7.28^{\mathrm{d}}$ & $607.79 \pm 24.31^{\mathrm{a}}$ \\
\hline Serine & $110.17 \pm 4.41^{\mathrm{c}}$ & $310.36 \pm 12.41^{b}$ & $110.82 \pm 4.43^{\mathrm{c}}$ & $299.94 \pm 12.00^{\mathrm{b}}$ & $104.95 \pm 4.20^{\mathrm{c}}$ & $343.17 \pm 13.73^{\mathrm{a}}$ \\
\hline Glutamic acid & $603.87 \pm 24.15^{\mathrm{d}}$ & $1,233.90 \pm 49.36^{c}$ & $473.98 \pm 18.96^{\mathrm{e}}$ & $1,416.23 \pm 56.65^{b}$ & $465.06 \pm 18.60^{\mathrm{e}}$ & $1,676.82 \pm 67.07^{\mathrm{a}}$ \\
\hline Sarcosine & $22.42 \pm 0.90^{\mathrm{a}}$ & $16.92 \pm 0.68^{\mathrm{b}}$ & $29.86 \pm 1.19^{\mathrm{a}}$ & $17.23 \pm 0.69^{b}$ & $22.53 \pm 0.90^{\mathrm{a}}$ & $24.60 \pm 0.98^{\mathrm{a}}$ \\
\hline Aminoadipic acid & $34.75 \pm 1.39^{c}$ & $49.76 \pm 1.99^{b}$ & $32.10 \pm 1.28^{\mathrm{c}}$ & $49.88 \pm 2.00^{\mathrm{b}}$ & $37.06 \pm 1.48^{\mathrm{c}}$ & $59.46 \pm 2.38^{\mathrm{a}}$ \\
\hline Glycine & $59.38 \pm 2.38^{\mathrm{c}}$ & $169.16 \pm 6.77^{b}$ & $56.34 \pm 2.25^{\mathrm{c}}$ & $166.36 \pm 6.65^{b}$ & $58.34 \pm 2.33^{\mathrm{c}}$ & $189.96 \pm 7.60^{\mathrm{a}}$ \\
\hline Alanine & $122.93 \pm 4.92^{\mathrm{d}}$ & $277.99 \pm 11.12^{\mathrm{c}}$ & $125.45 \pm 5.02^{\mathrm{d}}$ & $373.22 \pm 14.93^{\mathrm{a}}$ & $136.18 \pm 5.45^{\mathrm{d}}$ & $331.52 \pm 13.26^{b}$ \\
\hline Citrulline & $8.34 \pm 0.33^{\mathrm{d}}$ & $11.41 \pm 0.46^{d}$ & $17.35 \pm 0.69^{\mathrm{d}}$ & $45.97 \pm 1.84^{\mathrm{b}}$ & $26.32 \pm 1.05^{\mathrm{c}}$ & $73.66 \pm 2.95^{\mathrm{a}}$ \\
\hline a-aminobutyric acid & $15.75 \pm 0.63^{b}$ & $18.69 \pm 0.75^{\mathrm{b}}$ & $12.96 \pm 0.52^{\mathrm{b}}$ & $30.93 \pm 1.24^{\mathrm{a}}$ & $16.22 \pm 0.65^{b}$ & $39.78 \pm 1.59^{\mathrm{a}}$ \\
\hline Cystine & $47.25 \pm 1.89^{\mathrm{a}}$ & $44.73 \pm 1.79^{\mathrm{a}}$ & $13.53 \pm 0.54^{\mathrm{c}}$ & $44.78 \pm 1.79^{\mathrm{a}}$ & $35.36 \pm 1.41^{\mathrm{b}}$ & $50.24 \pm 2.01^{\mathrm{a}}$ \\
\hline Cystathionine & $13.69 \pm 0.55^{b}$ & $12.45 \pm 0.50^{b}$ & $12.06 \pm 0.48^{b}$ & $17.04 \pm 0.68^{\mathrm{a}}$ & $12.71 \pm 0.51^{b}$ & $20.63 \pm 0.83^{\mathrm{a}}$ \\
\hline Tyrosine & $138.59 \pm 0.54^{\mathfrak{c}}$ & $290.28 \pm 11.61^{\mathrm{b}}$ & $140.06 \pm 5.60^{c}$ & $295.37 \pm 11.81^{\mathrm{b}}$ & $148.77 \pm 5.95^{\mathrm{c}}$ & $355.43 \pm 14.22^{\mathrm{a}}$ \\
\hline b-alanine & $34.30 \pm 1.37^{\mathrm{c}}$ & $64.83 \pm 2.59^{\mathrm{a}}$ & $38.85 \pm 1.55^{\mathfrak{c}}$ & $55.15 \pm 2.21^{\mathrm{b}}$ & $41.07 \pm 1.64^{c}$ & $60.28 \pm 2.41^{\mathrm{a}}$ \\
\hline b-aminoisobutyric acid & $102.19 \pm 4.09^{\mathrm{a}}$ & $57.38 \pm 2.30^{\mathrm{d}}$ & $56.55 \pm 2.26^{\mathrm{d}}$ & $66.96 \pm 2.68^{c}$ & $91.37 \pm 3.65^{b}$ & $82.83 \pm 3.31^{\mathrm{b}}$ \\
\hline $\mathrm{\gamma}$-aminobutyric acid & $35.46 \pm 1.42^{\mathrm{d}}$ & $24.93 \pm 1.00^{\mathrm{e}}$ & $63.73 \pm 2.55^{\mathrm{c}}$ & $71.95 \pm 2.88^{\mathrm{c}}$ & $108.53 \pm 4.34^{b}$ & $129.87 \pm 5.19^{\mathrm{a}}$ \\
\hline Aminoethanol & $13.96 \pm 0.56^{\mathrm{a}}$ & $8.11 \pm 0.32^{b}$ & $9.97 \pm 0.40^{b}$ & $15.02 \pm 0.60^{\mathrm{a}}$ & $19.44 \pm 0.78^{\mathrm{a}}$ & $21.95 \pm 0.88^{\mathrm{a}}$ \\
\hline Hydroxylysine & $11.73 \pm 0.47^{\mathrm{a}}$ & $11.70 \pm 0.47^{\mathrm{a}}$ & $8.51 \pm 0.34^{b}$ & $18.00 \pm 0.72^{\mathrm{a}}$ & $16.51 \pm 0.66^{\mathrm{a}}$ & $17.85 \pm 0.71^{\mathrm{a}}$ \\
\hline Ornithine & $13.49 \pm 0.54^{\mathrm{c}}$ & $32.15 \pm 1.29^{b}$ & $15.33 \pm 0.61^{\mathrm{c}}$ & $63.24 \pm 2.53^{\mathrm{a}}$ & $18.26 \pm 0.73^{\mathrm{c}}$ & $18.62 \pm 0.74^{\mathrm{c}}$ \\
\hline Anserine & $65.11 \pm 5.60^{c}$ & $68.58 \pm 2.74^{c}$ & $77.22 \pm 3.09^{b}$ & $69.52 \pm 2.78^{c}$ & $82.97 \pm 3.32^{\mathrm{b}}$ & $105.66 \pm 4.23^{\mathrm{a}}$ \\
\hline Carnosine & $18.55 \pm 0.74^{\mathrm{a}}$ & $4.41 \pm 0.18^{\mathrm{b}}$ & $7.96 \pm 0.32^{b}$ & $5.20 \pm 0.21^{\mathrm{b}}$ & $5.67 \pm 0.23^{\mathrm{b}}$ & $13.72 \pm 0.55^{\mathrm{a}}$ \\
\hline Arginine & $304.17 \pm 12.17^{\mathrm{d}}$ & $533.96 \pm 21.36^{b}$ & $336.92 \pm 13.48^{\mathrm{d}}$ & $459.82 \pm 18.39^{c}$ & $393.39 \pm 15.74^{d}$ & $641.05 \pm 25.64^{\mathrm{a}}$ \\
\hline Totals & $2,058.97 \pm 82.36^{\mathrm{c}}$ & $4,157.48 \pm 166.30^{b}$ & $2,386.17 \pm 95.45^{\mathrm{c}}$ & $4,358.44 \pm 174.34^{b}$ & $2,264.14 \pm 90.57^{c}$ & $5,486.41 \pm 219.46^{\mathrm{a}}$ \\
\hline \multicolumn{7}{|l|}{ Essential amino acid } \\
\hline Threonine & $74.39 \pm 2.98^{\mathrm{b}}$ & $236.02 \pm 9.44^{\mathrm{a}}$ & $82.03 \pm 3.28^{b}$ & $219.97 \pm 8.80^{\mathrm{a}}$ & $80.61 \pm 3.22^{\mathrm{b}}$ & $253.57 \pm 10.14^{\mathrm{a}}$ \\
\hline Valine & $118.78 \pm 4.75^{\mathrm{b}}$ & $326.53 \pm 13.06^{\mathrm{a}}$ & $128.11 \pm 5.12^{\mathrm{b}}$ & $311.13 \pm 12.45^{\mathrm{a}}$ & $136.11 \pm 5.44^{\mathrm{b}}$ & $376.29 \pm 15.05^{\mathrm{a}}$ \\
\hline Methionine & $57.26 \pm 2.29^{b}$ & $106.29 \pm 4.25^{\mathrm{a}}$ & $59.18 \pm 2.37^{\mathrm{b}}$ & $101.51 \pm 4.06^{\mathrm{a}}$ & $68.54 \pm 2.74^{b}$ & $121.12 \pm 4.84^{\mathrm{a}}$ \\
\hline Isoleucine & $112.12 \pm 4.48^{\mathrm{b}}$ & $310.30 \pm 12.41^{\mathrm{a}}$ & $109.27 \pm 4.37^{b}$ & $300.45 \pm 12.02^{\mathrm{a}}$ & $120.05 \pm 4.80^{\mathrm{b}}$ & $352.14 \pm 14.09^{\mathrm{a}}$ \\
\hline Leucine & $229.71 \pm 9.19^{c}$ & $496.64 \pm 19.87^{\mathrm{b}}$ & $235.06 \pm 9.40^{c}$ & $487.16 \pm 19.49^{b}$ & $248.56 \pm 9.94^{c}$ & $586.08 \pm 23.44^{\mathrm{a}}$ \\
\hline Phenylalanine & $220.63 \pm 8.83^{c}$ & $375.54 \pm 15.02^{\mathrm{b}}$ & $227.48 \pm 9.10^{\mathrm{c}}$ & $378.15 \pm 15.13^{b}$ & $238.78 \pm 9.55^{\mathrm{c}}$ & $454.84 \pm 18.19^{\mathrm{a}}$ \\
\hline Lysine & $218.99 \pm 8.76^{c}$ & $398.24 \pm 15.93^{\mathrm{b}}$ & $225.24 \pm 9.01^{\mathrm{c}}$ & $386.05 \pm 15.44^{\mathrm{b}}$ & $240.17 \pm 9.61^{\mathrm{c}}$ & $465.54 \pm 18.62^{\mathrm{a}}$ \\
\hline Histidine & $53.97 \pm 2.16^{c}$ & $122.22 \pm 4.89^{\mathrm{a}}$ & $63.40 \pm 2.54^{b}$ & $125.72 \pm 5.03^{\mathrm{a}}$ & $73.26 \pm 2.93^{b}$ & $153.26 \pm 6.13^{\mathrm{a}}$ \\
\hline Totals & $1,085.85 \pm 43.34^{\mathrm{b}}$ & $2,371.77 \pm 94.87^{\mathrm{a}}$ & $1,129.77 \pm 45.19^{b}$ & $2,310.14 \pm 92.41^{\mathrm{a}}$ & $1,206.07 \pm 48.24^{b}$ & $2,762.84 \pm 110.51^{\mathrm{a}}$ \\
\hline Total amino acids & $3,144.82 \pm 125.79^{c}$ & $6,529.25 \pm 261.17^{b}$ & $3,515.95 \pm 140.64^{\mathrm{c}}$ & $6,668.58 \pm 266.74^{b}$ & $3,470.21 \pm 138.81^{\mathrm{c}}$ & $8,249.25 \pm 329.97^{\mathrm{a}}$ \\
\hline Ammonia & $67.09 \pm 2.68^{c}$ & $102.54 \pm 4.10^{\mathrm{a}}$ & $82.77 \pm 3.31^{b}$ & $112.49 \pm 4.50^{\mathrm{a}}$ & $99.34 \pm 3.97^{\mathrm{b}}$ & $141.57 \pm 5.66^{\mathrm{a}}$ \\
\hline $\begin{array}{l}{ }^{1} \mathrm{U} \text { UFD, Unfermented Doenjang } \\
\text { 2) } \mathrm{FD} \text {, Fermented Doenjang (6 } \\
\text { 3) All values are means of det } \\
\text { Doenjang and fermented Do } \\
\text { (4) }\end{array}$ & the & st. & & & s. $\quad$ त & ences of unfer \\
\hline
\end{tabular}


않았으나 발효 60 일째에 조금씩 생성되었고 proline은 여주 첨가 $10 \%$ 된장을 제외하고 모두 발효 초기에 여주 첨가량 이 증가할수록 proline 함량도 증가하는 경향을 나타내었고 발효 후에는 모두 증가하였다. 이외에도 aspartic acid, serine, aminoadipic acid, glycine, alanine, citrulline 등 대부분 의 비 필수아미노산들은 모두 발효 초기보다 후에 증가하는 경향을 나타내었다. 한편 발효 초기의 주요 아미노산은 glutamic acid로 $0 \%(603.87 \mathrm{mg} / 100 \mathrm{~g}), 2.5 \%(528.64 \mathrm{mg} / 100$ $\mathrm{g}), 5 \%(473.98 \mathrm{mg} / 100 \mathrm{~g}), 7.5 \%(486.78 \mathrm{mg} / 100 \mathrm{~g})$, 그리고 $10 \%$ 여주된장은 $465.06 \mathrm{mg} / 100 \mathrm{~g}$ 을 함유하고 있었다. 발효 가 진행됨에 따라 glutamic acid는 더욱 증가하였고 이때 $10 \%$ 여주된장이 $1,676.82 \mathrm{mg} / 100 \mathrm{~g}$ 으로 가장 높은 함량을 나타내었다. $\gamma$-Aminobutryic acid(GABA)는 여주를 첨가하 지 않은 된장을 제외하고는 모두 발효 초기보다 후에 증가 하였고 이 역시 $10 \%$ 여주된장이 $129.87 \mathrm{mg} / 100 \mathrm{~g}$ 으로 가장 높은 것으로 나타났다. 한편 필수 아미노산 중에서는 leucine, phenylalanine 및 lysine이 가장 많이 존재하였고 이 또한 발효 과정 중 크게 증가하였다. 한편 $10 \%$ 여주된장 의 경우 각각 $586.08,454.54$, 및 $465.54 \mathrm{mg} / 100 \mathrm{~g}$ 으로 가장 많이 함유하고 있었으며 총 유리아미노산 함량 역시 $8,249.25 \mathrm{mg} / 100 \mathrm{~g}$ 으로 가장 높았다(Table 2).

Park 등(23)과 Park 등(24)은 시판된장의 경우 glutamic acid가 가장 많았으며 필수 아미노산 중에서는 leucine, lysine, valine 순이라 하여 본 연구와도 결과와도 유사하였 다. 또한 된장 종류에 따라 유리아미노산 조성은 다소 차이 가 있을 수 있지만 일반적으로 glutamic acid등이 비교적 많이 검출된다고 Park 등(25)은 보고하였고, Kim 및 Rhee(26)의 연구 결과 또한 유사한 것으로 나타났다. 이와 같은 유리아미노산 조성은 된장 제조 시 발효 미생물의 사용여부와 함께 재료 배합, 발효기간, 발효 조건 등에 따라 유리아미노산 함량이 다르게 나타날 수 있을 것으로 판단되 었다.

\section{여주 첨가 된장 발효 중 총 phenolics 함량 변화}

여주 첨가 된장 발효 중 총 phenolics 함량 변화는 Fig. 1 과 같았다.

총 phenolics 함량은 숙성 초기에 여주를 $10 \%$ 첨가한 된장이 가장 높았으며 여주를 첨가하지 않은 된장은 가장 낮은 함량을 나타내었다. 여주를 첨가하지 않은 된장의 경 우에는 발효 전 $9.27 \mathrm{GAE} \mathrm{mg/g}$ 에서 발효 후에는 13.49 $\mathrm{GAE} \mathrm{mg} / \mathrm{g}$ 으로 증가하였고 $5 \%$ 는 $10.30 \mathrm{GAE} \mathrm{mg/g}$ 에서 $13.62 \mathrm{GAE} \mathrm{mg} / \mathrm{g}, 10 \%$ 는 $11.87 \mathrm{GAE} \mathrm{mg} / \mathrm{g}$ 에서 $14.52 \mathrm{GAE}$ $\mathrm{mg} / \mathrm{g}$ 의 수준으로 여주 분말의 첨가량과 된장의 발효 기간 이 증가할수록 총 phenolics 함량도 증가하였다(Fig. 1).

식물체내의 phenolics 화합물들은 2 차산물로 생리활성을 나타낸다고 알려져 있으며(27), 일반적으로 된장과 청국장 (28)이나 두유와 같은 콩을 발효 시킬 때 많이 증가한다는
보고들도 있다(17). 한편 Boo 등(29)은 품종별 여주들에 대해 총 phenolics 화합물을 비교 분석하였고 한국 재래종의 경우 $16.82 \mu \mathrm{g} / \mathrm{g}$ 로 가장 많은 양을 함유한다고 하였다. 따라 서 이러한 결과를 바탕으로 본 연구의 여주 첨가 된장의 경우 역시 본래 여주가 함유하고 있는 phenolics 화합물과 된장의 발효 과정 중 발효미생물에 의해 콩으로부터 phenolics 화합물들이 증가한 것으로 판단된다. 한편 phenolics 화합물들의 높은 함량은 항산화 활성과도 상호관 계가 큰 것으로 보고되어있다(27).

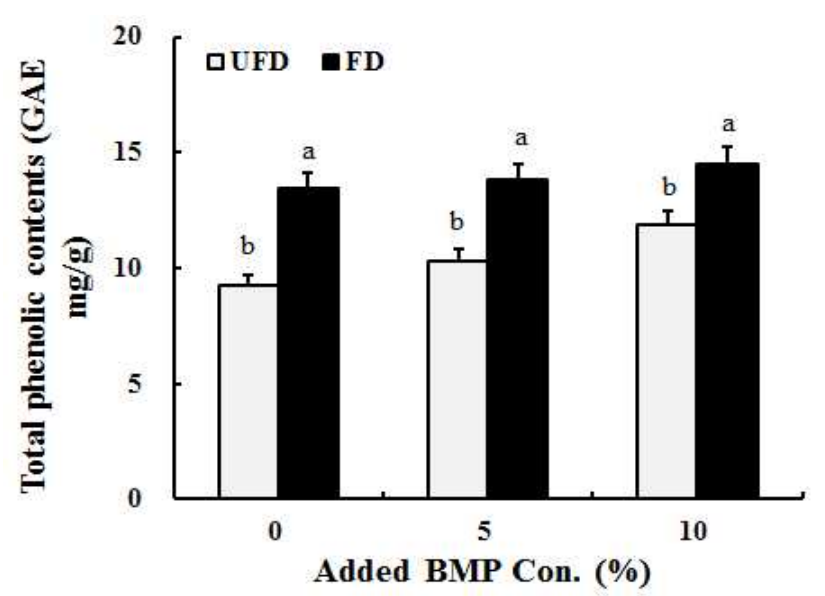

Fig. 1. Changes of total phenolic acid contents during the fermentation of Doenjang without and with bitter melon powder (BMP).

All values are means of determination in three independent experiments. Means with different lowercase letters $(a-b)$ indicate significant $(p<0.05)$ differences of unfermented Doenjang and fermented Doenjang by Duncan's multiple range test.

UFD, Unfermented Doenjang (0 day); FD, Fermented Doenjang (60 day).

\section{여주 첨가 된장 발효 중 isoflavones 함량 변화}

여주 첨가별 된장의 이소플라본 함량 변화는 Table 3과 같다. 여주를 첨가하지 않은 된장을 제외하고 모든 된장에 서 공통적으로 3종의 배당체(daidzin, glycitin, 및 genistin)와 3종의 비배당체(daidzein, glycitein, 및 genistein)가 검출되 었다. 발효 초기 이소플라본 함량은 각각 $491.09 \mu \mathrm{g} / \mathrm{g}(10 \%)$, $652.22 \mu \mathrm{g} / \mathrm{g}(5 \%)$, 및 $689.32 \mu \mathrm{g} / \mathrm{g}(0 \%)$ 이 검출되었고 여주 첨가량이 많을수록 발효 초기 이소플라본 함량은 적게 나타 났다. 배당체와 비배당체에 따른 함량을 살펴보면 발효가 됨에 따라 daidzin, glycitin 및 genistin의 함량은 감소하였고 여주를 첨가하지 않은 된장은 발효 60 일째 배당체 형태가 모두 검출되지 않았다. 한편 이와는 반대로 비배당체 형태 인 daidzein, glycitein, 및 genistein은 발효 후에 증가하였다. 여주 무첨가 된장은 발효 60 일째 daidzein $(251.45 \mu \mathrm{g} / \mathrm{g})$, glycitein $(42.15 \mu \mathrm{g} / \mathrm{g})$, 그리고 genistein $(181.31 \mathrm{\mu g} / \mathrm{g})$ 함량이 여주를 첨가한 된장들보다 높은 것으로 나타났다. $2.5 \%$ 첨가 된장은 daidzein은 $189.30 \mu \mathrm{gg} / \mathrm{g}$, glycitein은 $41.10 \mathrm{\mu g} / \mathrm{g}$, genistein은 $152.04 \mu \mathrm{g} / \mathrm{g}$ 이 검출되었고 $5 \%$ 및 $10 \%$ 여주 첨가 된장은 공통적으로 된장 발효 후에 glycitein이 검출되지 
않았다. 한편 발효 후 총 이소플라본 함량은 감소하였고 여주를 첨가하지 않은 된장은 발효 후 $474.91 \mu \mathrm{g} / \mathrm{g}$ 이었고 여주 $10 \%$ 첨가 된장은 $219.49 \mathrm{\mu g} / \mathrm{g}$ 으로 여주 함량이 높을수 록 총 이소플라본 함량은 낮게 나타나는 일관성 있는 결과 를 나타내었다(Table 3).

된장이나 청국장 그리고 유사 콩 발효식품들은 발효과정 중에 맛뿐만 아니라 이소플라본과 같은 기능성 물질들이 변화하게 된다(30). 특히 콩은 천연 항산화제로 알려져 있으 며 대부분의 이소플라본은 glycoside 접합체로 존재한다.
배당체 이소플라본 중 일부분은 섭취 시 직접 흡수되지 만 대부분 장내 세균의 B-glucosidase에 의해 가수분해 되어 비배당체 형태인 aglycone으로 전환된다(31). McCue 및 Shett(32)는 콩 발효 중에는 생체 이용률이 높은 daidzein, glycitein, 및 genistein으로 전환되며 이는 항산화 활성 또한 우수하다고 보고하였다. Jo 등(30)도 전통된장 숙성 중 배당 체는 감소하고 비배당체는 증가한다 하였고 이는 본 연구와 도 유사하였다. 따라서 본 연구에서는 숙성 과정 중 Bacillus subtilis 가 생성하는 $\beta$-glucosidase 활성에 의해 배당체는 감

Table 3. Changes of isoflavone contents during the fermentation of Doenjang without and with bitter melon

\begin{tabular}{|c|c|c|c|c|c|c|}
\hline \multirow{3}{*}{ Contents ( $\mu \mathrm{g} / \mathrm{g})$} & \multicolumn{6}{|c|}{ Added bitter melon powder concentration (\%) } \\
\hline & \multicolumn{2}{|c|}{0} & \multicolumn{2}{|c|}{5} & \multicolumn{2}{|c|}{10} \\
\hline & $\mathrm{UFD}^{1)}$ & $\mathrm{FD}^{2)}$ & UFD & FD & UFD & FD \\
\hline \multicolumn{7}{|c|}{ Glycosides } \\
\hline Daidzin & $218.15 \pm 8.73^{\mathrm{a3})}$ & $\mathrm{ND}^{4)}$ & $181.74 \pm 7.27^{\mathrm{b}}$ & $35.45 \pm 1.42^{\mathrm{c}}$ & $158.25 \pm 6.33^{\mathrm{b}}$ & $31.68 \pm 1.27 \mathrm{c}$ \\
\hline Glycitin & $100.82 \pm 4.03^{\mathrm{a}}$ & $\mathrm{ND}$ & $82.31 \pm 3.29^{b}$ & $33.08 \pm 1.32^{c}$ & $86.71 \pm 3.47^{b}$ & $24.77 \pm 0.99^{\mathrm{d}}$ \\
\hline Genistin & $262.02 \pm 10.48^{\mathrm{a}}$ & $\mathrm{ND}$ & $203.92 \pm 8.16^{b}$ & $\mathrm{TR}^{5)}$ & $191.42 \pm 7.66^{b}$ & $\mathrm{ND}$ \\
\hline Total & $580.99 \pm 25.11^{\mathrm{a}}$ & - & $467.97 \pm 20.24^{b}$ & $68.53 \pm 2.54^{\mathrm{c}}$ & $436.38 \pm 18.77^{\mathrm{b}}$ & $56.45 \pm 2.09^{\mathrm{c}}$ \\
\hline \multicolumn{7}{|l|}{ Aglycones } \\
\hline Daidzein & $120.49 \pm 4.80^{b}$ & $251.45 \pm 10.06^{\mathrm{a}}$ & $19.53 \pm 0.78^{d}$ & $46.21 \pm 1.59^{c}$ & $14.48 \pm 0.58^{\mathrm{d}}$ & $35.77 \pm 1.43^{\mathrm{c}}$ \\
\hline Glycitein & $28.20 \pm 1.13^{\mathrm{b}}$ & $42.15 \pm 1.69^{\mathrm{a}}$ & $1.10 \pm 0.04^{\mathrm{c}}$ & $\mathrm{ND}$ & TR & $\mathrm{ND}$ \\
\hline Genistein & $72.66 \pm 2.91^{\mathrm{c}}$ & $181.31 \pm 7.25^{\mathrm{a}}$ & $50.6 \pm 2.20^{\mathrm{d}}$ & $171.23 \pm 6.08^{\mathrm{a}}$ & $40.23 \pm 1.61^{d}$ & $127.27 \pm 5.09^{b}$ \\
\hline Totals & $221.35 \pm 9.87^{\mathrm{b}}$ & $474.91 \pm 20.23^{\mathrm{a}}$ & $71.23 \pm 2.87^{\mathrm{d}}$ & $217.44 \pm 10.65^{\mathrm{b}}$ & $54.71 \pm 1.68^{\mathrm{e}}$ & $163.04 \pm 5.89^{\mathrm{c}}$ \\
\hline Total isoflavone & $802.34 \pm 27.57^{a}$ & $474.91 \pm 19.00^{c}$ & $539.2 \pm 26.09^{b}$ & $285.97 \pm 11.44^{d}$ & $491.09 \pm 19.64^{c}$ & $219.49 \pm 8.78^{\mathrm{e}}$ \\
\hline
\end{tabular}

Table 4. Changes of phenolic acid contents during the fermentation of Doenjang without and with bitter melon

\begin{tabular}{|c|c|c|c|c|c|c|}
\hline \multirow{3}{*}{ Contents $(\mu \mathrm{g} / \mathrm{g})$} & \multicolumn{6}{|c|}{ Added bitter melon powder concentration (\%) } \\
\hline & \multicolumn{2}{|c|}{0} & \multicolumn{2}{|c|}{5} & \multicolumn{2}{|c|}{10} \\
\hline & $\mathrm{UFD}^{1)}$ & $\mathrm{FD}^{2)}$ & UFD & FD & UFD & FD \\
\hline Gallic acid & $32.11 \pm 1.33^{(3)}$ & $62.63 \pm 6.51^{\mathrm{b}}$ & $54.78 \pm 1.54^{\mathrm{b}}$ & $94.15 \pm 7.77^{\mathrm{a}}$ & $98.13 \pm 2.01^{\mathrm{a}}$ & $113.56 \pm 8.54^{\mathrm{a}}$ \\
\hline Protocatechuic acid & $80.3 \pm 11.21^{\mathrm{f}}$ & $163.72 \pm 22.55^{\mathrm{c}}$ & $115.88 \pm 12.64^{\mathrm{e}}$ & $180.32 \pm 26.41^{\mathrm{b}}$ & $135.86 \pm 13.43^{\mathrm{d}}$ & $203.04 \pm 29.32^{\mathrm{a}}$ \\
\hline p-Hydrobenzoic acid & $97.43 \pm 3.90^{\mathrm{a}}$ & $114.66 \pm 4.59^{\mathrm{a}}$ & $75.34 \pm 3.01^{\mathrm{b}}$ & $110.13 \pm 4.41^{\mathrm{a}}$ & $64.05 \pm 2.56^{\mathrm{b}}$ & $97.97 \pm 3.92^{\mathrm{a}}$ \\
\hline Chlorgenic acid & $29.59 \pm 4.78^{\mathrm{f}}$ & $127.59 \pm 9.10^{\mathrm{c}}$ & $51.17 \pm 6.05^{\mathrm{e}}$ & $142.15 \pm 9.29^{b}$ & $98.92 \pm 7.96^{\mathrm{d}}$ & $169.71 \pm 10.79^{\mathrm{a}}$ \\
\hline Vanilic acid & $7.83 \pm 0.31^{\mathrm{e}}$ & $23.85 \pm 4.95^{\mathrm{c}}$ & $15.16 \pm 0.61^{\mathrm{d}}$ & $35.81 \pm 3.83^{\mathrm{b}}$ & $17.81 \pm 0.71^{\mathrm{d}}$ & $50.61 \pm 2.82^{\mathrm{a}}$ \\
\hline Veratric acid & $24.22 \pm 8.17^{\mathrm{a}}$ & $16.55 \pm 0.53^{\mathrm{b}}$ & $25.95 \pm 8.64^{\mathrm{a}}$ & $19.69 \pm 0.99^{\mathrm{b}}$ & $23.23 \pm 8.92^{\mathrm{a}}$ & $20.78 \pm 1.45^{\mathrm{a}}$ \\
\hline $\mathrm{t}$-Cinnamic acid & $20.03 \pm 0.80^{\mathrm{d}}$ & $49.59 \pm 1.93^{c}$ & $23.08 \pm 2.53^{\mathrm{d}}$ & $62.26 \pm 2.60^{b}$ & $26.20 \pm 2.66^{d}$ & $73.28 \pm 2.44^{\mathrm{a}}$ \\
\hline Total & $291.51 \pm 33.78^{f}$ & $558.59 \pm 42.64^{\mathrm{c}}$ & $361.36 \pm 30.12^{\mathrm{e}}$ & $644.51 \pm 45.55^{\mathrm{b}}$ & $464.2 \pm 36.22^{\mathrm{d}}$ & $728.95 \pm 66.14^{\mathrm{a}}$ \\
\hline
\end{tabular}

${ }^{1)} \mathrm{UFD}$, Unfermented Doenjang (0 day).

${ }^{2)} \mathrm{FD}$, Fermented Doenjang (60 day).

${ }^{3)}$ All values are means of determination in three independent experiments. Means with different lowercase letters $(a-f)$ indicate significant $(\mathrm{p}<0.05)$ differences of unfermented Doenjang and fermented Doenjang by Duncan's multiple range test. 
소하고 비배당체는 증가한 것으로 판단된다.

여주 첨가 된장 발효 중 phenolic acids 함량 변화

여주 첨가 된장의 phenolic acids 화합물의 변화는 Table 4에 나타내었다. 모든 된장에서 gallic acid, protocatechuic acid, p-hydrobenzoic acid, chlorgenic acid, vanillic acid, veratric acid 및 t-cinnamic acid 7 종의 phenolic acids 유도체 가 검출되었고, 발효 후 veratric acid를 제외하고 모두 증가 하는 경향을 보였다. 발효 전 된장의 주요 phenolic acids 유도체는 protocatechuic acid 및 p-hydrobenzoic acid로 각각 $80.3 \mu \mathrm{g} / \mathrm{g}(0 \%), 115.88 \mu \mathrm{g} / \mathrm{g}(5 \%), 135.86 \mu \mathrm{g} / \mathrm{g}(10 \%)$ 및 97.43 $\mu \mathrm{g} / \mathrm{g}(0 \%), 75.34 \mu \mathrm{g} / \mathrm{g}(5 \%), 64.05 \mu \mathrm{g} / \mathrm{g}(10 \%)$ 있었고, 발효 후 증가하여 각각 $163.72 \mu \mathrm{g} / \mathrm{g}(0 \%), 180.32 \mu \mathrm{g} / \mathrm{g}(5 \%), 203.04$ $\mu \mathrm{g} / \mathrm{g}(10 \%)$ 및 $114.66 \mu \mathrm{g} / \mathrm{g}(0 \%), 110.13 \mu \mathrm{g} / \mathrm{g}(5 \%)$ 및 97.97 $\mathrm{\mu g} / \mathrm{g}(10 \%)$ 있었다. 한편 발효 후에는 gallic acid와 chlorgenic acid가 급격히 증가하여 각각 $62.63 \mu \mathrm{g} / \mathrm{g}(0 \%), 94.15 \mu$ $\mathrm{g} / \mathrm{g}(5 \%), 113.56 \mu \mathrm{g} / \mathrm{g}(10 \%)$ 및 $127.59 \mu \mathrm{g} / \mathrm{g}(0 \%), 142.15 \mu$
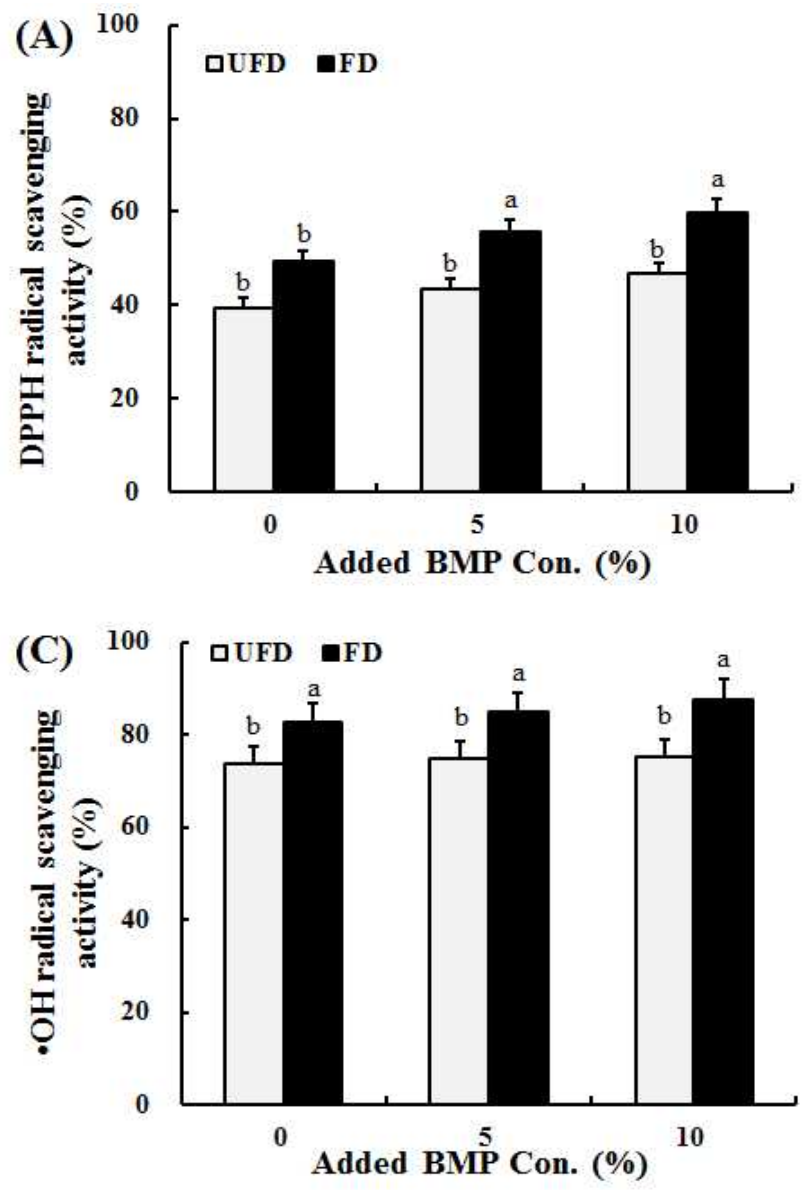

$\mathrm{g} / \mathrm{g}(5 \%), 169.71 \mu \mathrm{g} / \mathrm{g}(10 \%)$ 있었다(Table 4).

일반적으로 phenolic acid는 벤젠 핵에 페놀성 수산화기 $(\mathrm{OH})$ 와 카복실기 $(\mathrm{COOH})$ 를 가지는 화합물이며 식용 가능 한 식물에 존재하고 생리활성이 뛰어난 것으로 알려져 있다 $(16,33)$. 콩 발효식품의 주요 phenolics 화합물로 gallic, protocatechuic, p-cumaric, caffeic, chlorogenic, gentisic, p-hydroxylbenzoic, vanillic 및 ferulic acids로 보고하였고 (34), 여주의 phenolic acid 역시 gallic, protocatechuic, p-Hydroxylbenzoic, vanillic, caffeic, chlorogenic, p-cumaric 및 ferulic acids를 보고하였다(35). 특히, Cho 등(34)은 청국 장 발효 과정 중에 $\mathrm{GA}$ 함량이 지속적으로 증가함으로써 $\mathrm{DPPH}$ 라디칼 소거활성이 증가한다고 보고하였다.

\section{여주 첨가 된장 발효 중 항산화 활성 변화}

여주 첨가 된장의 항산화 활성 [DPPH, ABTS, hydroxyl $(\cdot \mathrm{OH})$ 라디칼 소거활성 및 FRAP 환원력]을 측정한 결과 는 Fig. 2에 나타내었고, 전체적으로 항산화 활성은 여주
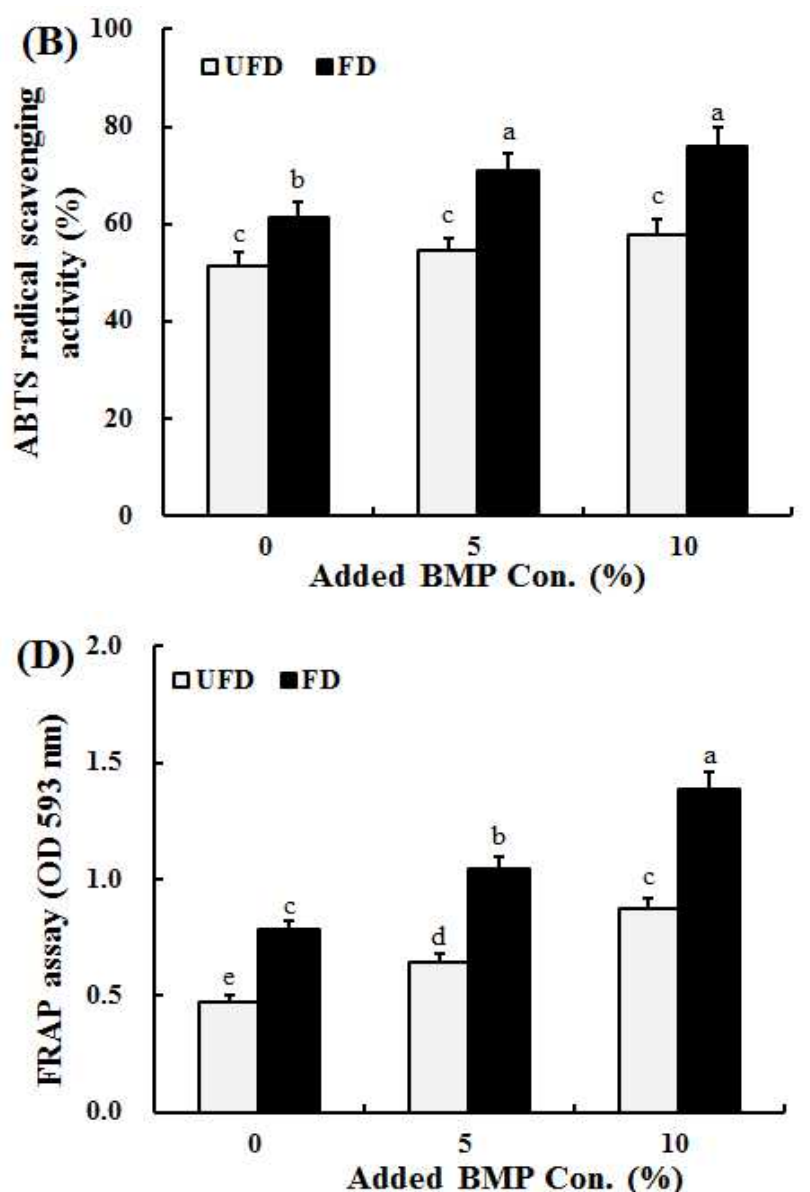

Fig. 2. Changes of antioxidant activity during the fermentation of Doenjang without and with bitter melon powder (BMP).

All values are means of determination in three independent experiments. Means with different lowercase letters $(\mathrm{a}-\mathrm{e})$ indicate significant $(\mathrm{p}<0.05)$ differences of unfermented Doenjang and fermented Doenjang by Duncan's multiple range test.

UFD, Unfermented Doenjang (0 day); FD, Fermented Doenjang (60 day)

A, DPPH radical scavenging activity; B, ABTS radical scavenging activity; $\mathrm{C}$, $\cdot \mathrm{OH}$ radical scavenging activity; D, FRAP assay. 
첨가량이 증가할수록 활성이 높았고, 발효 전보다는 발효 후가 높았다.

$\mathrm{DPPH}$ 라디칼 소거활성은 발효 후에 증가하는 경향을 보여, 여주를 첨가하지 않은 된장은 발효 전 $22.56 \%$ 에서 발효 후에는 $37.61 \%$ 로 증가하였다. 여주 첨가량이 많아질 수록 발효 전 DPPH 라디칼 소거활성은 조금씩 증가하였고 발효가 끝난 시점인 60 일째 역시 증가하여 $10 \%$ 여주 첨가 된장은 $25 \%$ 에서 $64.17 \%$ 로 가장 우수하였다(Fig. 2A).

$\mathrm{ABTS}$ 라디칼 소거활성은 동일한 농도에서 $\mathrm{DPPH}$ 보다 는 약 2 배 이상 높은 활성을 나타내었고, 여주 첨가량에 따른 소거활성의 차이는 크게 없었다. 발효 초기부터 60 일 까지의 소거활성은 $0 \%$ 의 경우 $51.42 \%$ 에서 $61.31 \%$ 로 증가 하였고 가장 높은 활성을 나타낸 $10 \%$ 의 경우에는 $73.74 \%$ 에서 $82.66 \%$ 로 발효됨에 따라 소거활성 역시 증가함을 나 타내었다(Fig. 2B).

$\operatorname{Hydroxyl}(\cdot \mathrm{OH})$ 라디칼 소거활성 또한 여주 첨가량과의 상관관계는 없는 것으로 나타났고, 발효 후에 증가하여 $82.66 \%(0 \%), 84.88 \%(5 \%)$ 및 $87.63 \%(10 \%)$ 를 나타내었다 (Fig. 2C).

FRAP 환원력은 여주 첨가량이 증가할수록 숙성 초기 환원력도 비례하여 증가하였고 라디칼 소거활성과 유사하 게 발효 후에 환원력이 크게 증가하였다. 이때 $10 \%$ 여주된 장의 경우 1.39 의 가장 높은 환원력을 나타내었다(Fig. 2D).

된장의 우수한 라디칼 소거활성은 발효 과정 중에 저분 자 phenolic acid 화합물들과 비배당체 이소플라본으로의 증가가 원인인 것으로 판단되었다(36). 또한 Lee 등(37)은 증자콩에 존재하지 않았던 phenolic acid 함량이 된장 숙성 중에 증가하므로 항산화 활성이 증가한다고 보고하였고, Shon 등(38)은 청국장의 총 phenolics 함량이 $0.27 \mathrm{mg} / \mathrm{g}$ 일 때 $\mathrm{DPPH}$ 라디칼 소거활성은 $87 \%$ 를 나타낸다고 하였고 이는 phenolics 함량과 항산화 활성과의 관계가 밀접한 것으 로 판단된다. Cho 등(34) 역시 총 phenolics 함량이 증가함에 따라 항산화 활성도 증가함을 보고하였고 이는 본 연구 결과와도 경향이 유사하였다. 따라서 발효 미생물에 의해 생성된 phenolics 물질들과 비배당체 이소플라본 형태가 같이 공존할 경우 라디칼 소거활성과 FRAP 환원력이 상승 효과를 나타내는 것으로 판단된다.

\section{여주 첨가 된장 발효 중 탄수화물 분해효소 저해활성 변화}

a-Glucosidase 저해제는 식후 고혈당을 완화 시킬 수 있는 잠재적 능력을 보유하고 있다(39). 당뇨는 고혈당으로 인해 신장과 심혈관계 질환에 큰 손상을 준다는 점이 큰 특징이 다(40). 현재 당뇨의 지속적인 관리를 위하여 주로 $a$ -glucosidase 및 a-amylase 저해제를 경구 투여하여 사용하 고 있으며 이들은 소장의 a-glucosidase를 경쟁적 저해를 하여 당 흡수율을 감소시키고 대부분 반응물질인 $\mathrm{pNPG}$ 를 사용하여 평가한다고 보고되어있다(38).
따라서 본 연구의 a-glucosidase 저해활성을 측정한 결과 는 Fig. 3과 같았다. 전체적인 결과로는 DPPH 라디칼 소거 활성과 일관성 있는 결과를 나타내었다. 즉, 여주 첨가량이 많을수록 각각의 된장 발효 초기 저해율이 증가하는 것으로 나타났으며 발효 후에는 효소 저해활성도 전체적으로 증가 하는 것으로 나타났다. 여주를 첨가하지 않은 된장의 발효 초기 저해율은 $0.86 \%$ 로 거의 없는 것으로 나타났으나 발효 후에는 $23.64 \%$ 로 약간 증가하였다. $5 \%$ 의 경우에는 $27.74 \%$ 를 나타내었으며 $10 \%$ 여주된장은 $30.79 \%$ 로 가장 우수한 저해율을 나타내었다(Fig. 3).

한편 Hwang 등(41)의 결과에 따르면 전통 된장 메탄올 추출물에서 33.5-44.3\%의 저해율을 나타내었다고 하였고, Shukla 등(40) 역시 상업식 된장(20.66-25.55\%)보다 전통 된장(26.50-36.86\%)의 a-glucosidase 저해율이 우수하다고 보고하였다. 이러한 결과는 본 연구와도 유사한 것으로 판 단된다. 또한 이러한 콩 외에도 고구마에 함유된 phenolics 화합물들도 a-glucosidase 저해활성을 가진다는 연구 결과 도 있다(42). 따라서 본 연구의 여주 첨가 된장은 고혈당 개선뿐만 아니라 비만과 당뇨와 같은 질병을 치료 및 관리 하는데 효과가 있을 것으로 기대된다.

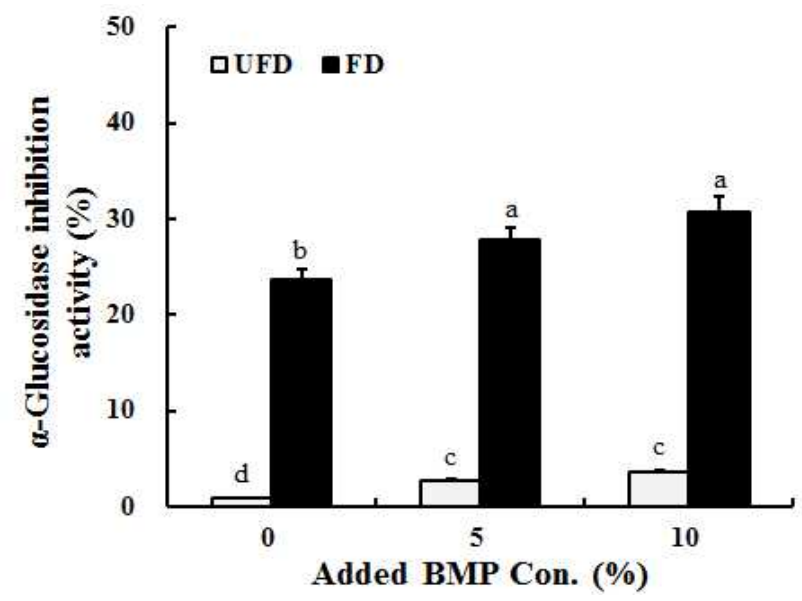

Fig. 3. Changes of a-glucosidase inhibition activity during the fermentation of Doenjang without and with bitter melon powder (BMP).

All values are means of determination in three independent experiments. Means with different lowercase letters $(a-d)$ indicate significant $(p<0.05)$ differences of unfermented Doenjang and fermented Doenjang by Duncan's multiple range test. UFD, Unfermented Doenjang (0 day); FD, Fermented Doenjang (60 day).

\section{요 약}

본 연구는 여주 분말 첨가 된장의 발효 중 이화학적 특성, phytochemical 화합물(isoflavones과 phenolic acids) 및 생리 활성 활성 변화를 측정하였다. 된장 발효 중 $\mathrm{pH}$ 는 6.41-5.83 에서 5.81-5.24로 감소하였고, 반면에 산도는 $0.42-0.65 \%$ 에 서 1.28-1.48\%로 증가하였다. 고초균과 효모 생균수, 염도 
및 총 아미노산 함량은 발효 종기(60 일)에 증가하였다. 특히, 발효 후 $10 \%$ 여주 분말 첨가 된장은 가바(GABA, $129.87 \mathrm{mg} / 100 \mathrm{~g}$ ) 함량이 다른 된장 시료들과 비교하여 가 장 함량이 높았다. 발효 후 된장은 발효 전 된장 시료보다 생리활성이 높았다. 발효 후 phytochemicals 화합물 중 isoflavone-aglycones과 phenolic acids는 증가하였고, 반면 에 isoflavone-glycosides는 감소하였다. 게다가, 발효 후에 총 phenolics, isoflavone-aglycones과 phenolic acids 함량은 급격히 증가하였고, 이에 따라 항산화 활성과 a-glucosidase 저해활성이 증가하였다. 이들 결과로부터 여주 분말 첨가 로 항산화와 항당뇨 활성이 개선된 새로운 타입의 된장 제조가 가능할 것으로 판단되었다.

\section{감사의 글}

본 논문은 농촌진흥청 공동연구사업(과제번호 : PJ00846101) 의 지원에 의하여 연구되었습니다.

\section{References}

1. Jung BM, Roh SB (2004) Physicochemical quality comparison of commercial Doenjang and traditional green tea Doenjang. J Korean Soc Food Sci Nutr, 33, 132-139

2. Kim SJ, Moon JS, Park JW, Park IB, Kim JM, Rhim JW, Jung ST, Kang SG (2004) Quality of soybean paste (Doenjang) prepared with sweet tangle, sea mustard and anchovy powder. J Korean Soc Food Sci Nutr, 33, 875-879

3. Kim SH (1998) New trends of studying on potential activities of Doenjang fibrinolytic activity. Korea Soybean Digest, 15, 8-15

4. Kwon SH, Shon MY (2004) Antioxidant and anticarcinogenic effects of traditional Doenjang during maturation periods. Korean J Food Preserv, 11, 461-467

5. Lee BK, Jang YS, Yi SY, Chung KS, Choi SY (1997) Immunomodulators extracted from Korean-style fermented soybean paste and their function: 1. Isolation of B cell mitogen from Korean-style fermented soybean paste. Korean J Immunol, 19, 559-569

6. Hwang SH, Chung HS, Youn KS (2004) Effect of pretreatment methods on quality changes in mushrooms (Pleurotus eryngii) during pickling with fermented soybean paste. J East Asian Soc Dietary Life, 14, 251-256

7. Kim SJ, Park CW, Park SJ, Kim YS, Cho HJ, Lim DK,
Kim JO, Lee JH, Ha YL (2003) Enhanced antitumorigenicity and antimutagenicity of Doenjang prepared from mushroom mycelia-cultured traditional Mejus. J Korean Soc Food Sci Nutr, 32, 143-148

8. Ahn MJ, Yuk HJ, Lee HY, Hwang CE, Jeong YS, Hong SY, Kwon OK, Kang SS, Kim HR, Park DS, Cho KM (2015) Effect of the enhanced biological activities and reduced bitter taste of bitter melon (Momordica charantia L.) by roasting. J Agric Life Sci, 49, 107-119

9. Subratty AH, Gurib-Fakim A, Mahomoodally F (2005) Bitter melon: an exotic vegetable with medicinal values. Nutr Food Sci, 35, 143-147

10. Jeong JH, Lee $\mathrm{SH}$, Hue JJ, Lee KN, Nam SY, Yun YW, Jeong SW, Lee YH, Lee BJ (2008) Effect of bitter melon (Momordica charantia) on anti-diabetic activity in C57BL/6J $d b / d b$ mice. Korean J Vet Res, 48, 327-336

11. Tsai TY, Chu LH, Lee CL, Pan TM (2009) Atherosclerosispreventing activity of lactic acid bacteria-fermented milk-soymilk supplemented with Momordica charantia. J Agric Food Chem, 57, 2065-2071

12. Alam S, Asad M, Asdaq SMB, Prasad VS (2009) Antiulcer activity of methanolic extract of Momordica charantia L. in rats. J Ethnopharmacol, 123, 464-469

13. Kim MW (2013) Effect of bitter melon on plasma blood glucose and cholesterol levels in streptozotocin induced diabetic rats. J East Asian Soc Dietary Life, 23, 704-712

14. Cho KM, Joo OS (2015) Change in phytoestrogen and antioxidant activity during fermentation of Cheonggukjang with bitter melon. Korean J Food Preserv, 22, 119-128

15. Seo WT, Cho HK, Lee JY, Kim B, Cho KM (2012) Quality characteristics of wheat-rice Makgeolli by making of rice Nuruk prepared by Rhizopus oryzae CCS01. Korean J Microbiol, 48, 147-155

16. Lee JH, Seo WT, Cho KM (2011) Dertermination of phytochemical contents and biological activities from the fruits of Elaeagnus multiflora. J Food Sci Nutr, 16, 29-36

17. Hwang CE, Ahn MJ, Lee HY, Lee BW, Kim HT, Ko JM, Baek IY, Seo WT, Cho KM (2014) Potential probiotic Lactobacillus plantarum P1201 to produce soy-yogurt with enhanced antioxidant activity. Korean J Food Sci Technol, 46, 556-565

18. Cho KM, Kang JR, Kim GM, Kang MJ, Hwang CE, Jeong YS, Kim JH, Lee CK, Shin JH (2014) Quality characteristics of low salted garlic Doenjang during fermentation. Korean J Food Preserv, 21, 627-635

19. Hong HJ, Rhee HS (1994) Characteristics of bitter peptides from Doenjang. Korean J Food Cook Sci, 10, 
45-50

20. Yang SH, Choi MR, Kim JK, Chung YG (1992) Characteristics of the taste in traditional Korean soybean paste. J Korean Soc Food Sci Nutr, 21, 443-448

21. Jun HI, Song GS (2012) Quality characteristics of Doenjang added with yam (Dioscorea batatas). J Agric Life Sci, 43, 54-58

22. Ahn MJ, Yuk HJ, Lee HY, Hwang CE, Jeong YS, Hong SY, Kwon OK, Kang SS, Kim HR, Park DS, Cho KM (2015) Effect of the enhanced biological activities and reduced bitter taste of bitter melon (Momordica charantia L.) by roasting. J Agric Life Sci, 49, 107-119

23. Park SK, Seo KI, Choi SH, Moon JS, Lee YH (2000) Quality assessment of commercial Doenjang prepared by traditional method. J Korean Soc Food Sci Nutr, 29, 211-217

24. Park SK, Seo KI, Shon MY, Moon JS, Lee YH (2000) Quality characteristics of home-made Doenjang, a traditional Korean soybean paste. Korean J Soc Food Cookery Sci, 16, 121-127

25. Park JS, Lee MY, Kim JS, Lee TS (1994) Compositions of nitrogen compound and amino acid in soybean paste (Doenjang) prepared with different microbial sources. Korean J Food Sci Technol, 26, 609-615

26. Kim MJ, Rhee HS (1988) The components of free amino acids nucleotides and their related compounds in soypaste made from native and improved meju and soypaste product. J Korean Soc Food Nutr, 17, 69-72

27. Lee YS (2007) Antioxidant and physiological activity of extracts of Angelica dahurica leaves. Korean J Food Preserv, 14, 78-86

28. Oh HJ, Kim CS (2007) Antioxidant and nitrite scavenging ability of fermented soybean foods (Chungkukjang, Doenjang). J Korean Soc Food Sci Nutr, 36, 1503-1510

29. Boo HO, Lee HH, Lee JW, Hwang SJ, Park SU (2009) Different of total phenolics and flavonoids, radical scavenging activities and nitrite scavenging effects of Momordica charntia L. according to cultivars. Korean J Medicinal Crop Sci, 17, 15-20

30. Jo SJ, Hong CO, Yang SY, Choi KK, Kim HK, Yang $\mathrm{H}$, Lee KW (2011) Changes in contents of $\mathrm{\gamma}$-aminobutyric acid (GABA) and isoflavones in traditional Korean Doenjang by ripening periods. J Korean Soc Food Sci Nutr, 40, 557-564

31. Kwak CS, Lee MS, Park SC (2007) Higher antioxidant properties of Chungkookjang, a fermented soybean paste, may be due to increased aglycon and malonylglycoside isoflavone during fermentation. Nutr Res, 27, 719-727

32. McCue P, Shetty K (2003) Role of carbohydrate-cleaving enzymes in phenolic antioxidant mobilization from whole soybean fermented with Rhizopus oligosporus. Food Biotechnol, 17, 27-37

33. Miliauskas G, Venskutonis RP, Van Beek TA (2004) Screening of radical scavenging activity of some medicinal and aromatic plant extracts. Food Chem, 85, 231-237

34. Cho KM, Lee JH, Yun HD, Ahn BY, Kim H, Seo WT (2011) Changes of phytochemical constituents (isoflavones, flavonols, and phenolic acids) during Cheonggukjang soybeans fermentation using potential probiotics Bacillus subtilis CS90. J Food Compos Anal, 24, 402-410

35. Choi JS, Kim HY, Seo WT, Lee JH, Cho KM (2012) Roasting enhances antioxidant effect of bitter melon (Momordica charantia L.) increasing in flavan-3-ol and phenolic acid contents. Food Sci Biotechnol, 21, 19-26

36. Jing H, Kitts DD (2000) Comparison of the antioxidative and cytotoxic properties of glucose-lysine and fructoselysine maillard reaction products. Food Res Int, 33, 509-516

37. Lee KH, Ryul SH, Lee YS, Kim YM, Moon GS (2005) Changes of antioxidative activity related compounds on the Chungkukjang preparation by adding drained boiling water. Korean Food Cookery Sci, 21, 163-170

38. Shon MY, Lee J, Choi JH, Choi SY, Nam SH, Seo KI, Lee SW, Sung NJ, Park SK (2007) Antioxidant and free radical scavenging activity of methanol extract of Chungkukjang. J Food Compos Anal, 20, 113-118

39. Liu G (2012) Chemical composition, a-glucosidase and a-amylase inhibitory activities of crude polysaccharides from the endodermis of shaddock (Citrus maxima). Arch Biol Sci Belgrade, 64, 71-76

40. Shukla S, Park JY, Kim DH, Hong SY, Lee JS, Kim MH (2016) Total phenolic content, antioxidant, tyrosinase and a-glucosidase

inhibitory activities of water soluble extracts of noble starter culture Doenjang, a Korean fermented soybean sauce variety. Food Control, 59, 854-861

41. Hwang JH, Oh YS, Lim JH, Park JE, Kim MB, Yoon HS, Lim SB (2009) Physiological properties of Jeju traditional Doenjang. J Korean Soc Food Sci Nutr, 38, 1656-1663

42. McDougall GJ, Stewart D (2005) The inhibitory effects of berry polyphenols on digestive enzymes. BioFactors, 23, 189-195 